\title{
Oral Endotracheal Tube
}

National Cancer Institute

\section{Source}

National Cancer Institute. Oral Endotracheal Tube. NCI Thesaurus. Code C122594.

A hollow tube that is directed into the trachea from the mouth. 